\title{
ENTREPRENEURIAL ORIENTATION, STRATEGIC IMPROVISATION, TALENT MANAGEMENT AND FIRM PERFORMANCE
}

\section{DOI: 10.17261/Pressacademia.201519953}

\author{
Hartini AHMAD' ${ }^{1}$, Darwina ARSHAD², Leonis MARCHALINA ${ }^{3}$ \\ ${ }^{1}$ Universiti Utara Malaysia. E-mail: hartini@uum.edu.my \\ ${ }^{2}$ Universiti Utara Malaysia. \\ ${ }^{3}$ Universiti Utara Malaysia. E-mail: leonismarchalina@gmail.com
}

\section{Keywords:}

entrepreneurial orientation, strategic improvisation, talent management, performance,

Government-Linked companies

\section{JEL Classification:}

\begin{abstract}
The Malaysian Government has acquired a large shareholding in several Malaysian companies to meet national aspirations, social concerns and global challenges. Known as 'Government-Linked Companies' or GLCs, have a part in ensuring Malaysia to achieve its ambition of becoming a developed country by the year of 2020. For the GLCs to sustain in the industry it is operated, it has to find ways to optimize the best practices such as in entrepreneurial orientation, strategic improvisation and talent management that can improve its organization competencies, particularly the performance. The sample includes all of the twenty six (26) public listed companies of the GLCs in Malaysia. The study uses a structured questionnaires to collect the data from the firms meeting the criteria of government linked companies or GLCs, the disproportionate sampling technique employed is to choose 5 executives from each company, making a total of 520 respondents. Results showed all hypotheses were supported; therefore, GLCs should ensure the favorable results to give the right priority to the implementation of the best practices in order to improve organizational performance.
\end{abstract}

\section{INTRODUCTION}

As the new venture development process unfolds, organisations typically need to change course from their original plans, remain flexible, become more entrepreneurial orientated and continually evolve their business (Mullins and Komisar, 2009). As a result, entrepreneurs must be able to formulate and execute novel strategic decisions in the moment (i.e., improvise) - so as to capitalize on opportunities to move their firm in a more promising direction. Entrepreneurial orientation (EO) as one of intangible resources (styles of thinking) has a willingness to explore new ideas and markets and attempts to destroy the market leader position by discovering new markets (Janney \& Dess, 2006). EO mostly focused on finding and proactively exploiting opportunity through innovation. 
Likewise improvisational activity in recent years has emerged as being critically important in the business arena. Improvisation enables managers to continually learn while working and act spontaneously and creatively to consistently move products and services out of the door (Brown \& Eisenhardt, 1997). It can potentially generate value to the company in terms of prudent change management, adjustability to adopt best practices as well as adding flexibility and innovation (Leybourne, 2006). By practicing improvisation, organizations could gain a better understanding on how individual and groups in organizations cope with and coordinate the conflicting demands of existing time perspectives (Crossan, Pina e Cunha, Vera, \& Cunha, 2005); learn and adapt under time pressures (Vera \& Crossan, 2005); and remain flexible under turbulent environments (Cunha, Cunha, \& Kamoche, 1999).

Since a group of McKinsey consultants coined the phrase the War for Talent in 1997 (see Axelrod et al., 2002), the topic of talent management has received a remarkable degree of practitioner and academic interest. People though belong to diverse backgrounds therefore possess diverse talents. So, this is an organization's responsibility to effectively manage the talent of its workforce to achieve better business performance. As defined by Tansley (2011), a high potential employee is someone with the ability, engagement and aspiration to rise to and succeed in more senior, more critical positions in order to be considered as high potential and it should have a critical skill set which has become difficult to be obtained in the labor market.

The Malaysian Government has acquired a large shareholding in several Malaysian companies to meet national aspirations, social concerns and global challenges (Vietor, 2007). Known as 'Government-Linked Companies' or GLCs (Ang \& Ding, 2006), they play a vital role in the country's economy. GLCs undoubtedly have been a major element in Malaysia's economic development, and need to be sustained as Ting \& Lean (2011) stated that the need for the future study to look into the sustainability issue in the GLC in a more holistic way. Despite the government's intervention, a number of them continued to underperform as reflected by key financial and operational indicators, and became a financial burden to the government (Musa, 2007). As such the study will examines how entrepreneurial orientation, strategic improvisation, talent management of GLCs's top management team can affect firm performance.

\section{LITERATURE REVIEW}

\subsection{Firm Performance}

Superior performance is usually based on developing a competitively distinct set of resources and deploying them in a well-conceived strategy (Fahy, 2000). Indeed, strategists who embrace the Resource-Based View (RBV) also point out that competitive advantage comes from aligning skills, motives, etc. with organizational systems, structures and processes that achieve capabilities at the organizational level (Salaman et al., 2005). Firms with a bundle of resources that are valuable, rare, inimitable and non-substitutable can implement value-creating strategies that are not easily duplicated by other firms (Barney, 1991). However, it is quite difficult to find a resource, which satisfies the entire VRIO or Valuable, Rarity, Imitability, and Organization criterion (Barney, 1991), except in a monopolistic type of company. VRIO concept is important in a company for indentifying the valuable resources and the performances of RBV in a company (Andersén, 2011). 
VRIO is a superior financial performance that are valuable, rare, and hard to imitate and have an organizational orientation that is attributed by RBV theory (Barney, 2002). VRIO was being studied to analyze competitive advantage (O'Sullivan and Bella, 2007; Andersén, 2011) and to discover the hidden capabilities and resources within the firm performance (Lin et al., 2012).

Firm performance using RBV can be classified into financial (accounting-based measures such as cash in hand at bank, profitability, sales growth, etc.) and non-financial (market share, new product introduction, product quality, marketing effectiveness or manufacturing value-added) (Kapelko, 2006). Profitability and sales growth is the most common measure of performance (Doyle, 1994). An effective firm performance measurement system ought to cover more than just financial measures (O'Regan \& Ghobadian, 2004). Recently, researchers have introduced several non-financial determinants of firm performance and the relative positioning of the firms against the leading competitor (Alegre et al., 2006). This type of measurement is becoming popular to overcome the limitation of financial measurements, such as a high probability of low response rate due to confidential data etc.

\subsection{Entrepreneurial Orientation}

Firms with high EO can target premium market segments, charge high prices and "skim" the market ahead of competitors, which should provide them with larger profits and allow them to expand faster (Zahra \& Covin, 1995). The relationship between the EO construct and non-financial goals, such as increasing the satisfaction of the owner of the firm, is less straightforward. Most researchers argue that there is little direct effect of EO on nonfinancial goals. Satisfaction may increase because of better financial firm performance. However, indirect effects are usually smaller than direct effects. Therefore, it appears reasonable to assume that the relationship should be higher for EO.

In addition, previous research suggests that every dimension has a positive influence on performance (McGrath, 2001). SMEs, which are innovative, can create new products and technologies, which generate unexpected economic firm performance, whereby proactive SMEs can create competitive advantage that dominates the market. On the other hand, the influence of risk taking and firm performance is still questionable as the result of a company's performance are varied while taking risky strategies (March. 1991).

H1: Entrepreneurial Orientation (EO) has significant positive relationship with performance

\subsection{Strategic Improvisation}

Prior research has paid considerable attention on the centrality of improvisation in individual and group outcomes (Kamoche et al., 2003) to the detriment of focus on organizational outcomes (firm performance). For instance, Moorman and Miner (1998) and Vera and Crossan (2005) study new product development as an improvisational outcome; Leybourne and Sadler-Smith (2006) investigates internal and external project outcomes; Souchon and Hughes (2007) focus on export performance as an outcome of export improvisation; while Hmieleski and Corbett (2008) examine venture performance as an outcome of entrepreneurial improvisational behavior. This relationship between improvisation and organizational outcomes has appeared to be dubious in extant research and lacks empirical examination (see Vera \& Crossan, 2005; Hmieleski \& Corbett, 2008). 
Interestingly, no study has sought to trace and prove the association between organizational improvisation and firm performance in GLCs, although many previous researchers tend to assume that improvisation may lead to superior performance through the secondary benefits of contingent factors such as flexibility (Crossan et al., 2005), selfefficacy (Hmieleski \& Corbett, 2008), and management of environmental turbulence. By noting this deficiency in the investigation of strategic improvisation in GLCs, this research seeks to provide additional contributions to existing theory and practitioners.

\section{H2: Strategic Improvisation (SI) has significant positive relationship with performance}

\subsection{Talent Management}

The ability to attract, develop and retain talent determines the strategic capability of organizations. The talent of the leadership within organizations is a break factor in the achievement of strategic goals and the incremental value of the best managers. Prior to that, many organizations are now realizing that attracting, growing and retaining top management talent is a strategic issue. Gagne (2000) suggests that talented people have the ability to perform an activity to a degree that places their achievement within at least the upper 10 percent of their peers who are active in that field.

Additionally, Goleman (2006) noted that in professional jobs, top performers who were capable of adding value to their organization are worth ten times as much as their coworkers. Thus, the strong human resource practices have been systematically associated with personnel measures (e.g. turnover as well as organizational performance was measured by objective (Huselid, 1995) and subjective criteria (Singh, 2004).

According to Tansley (2011), successful performance can also be linked to other characteristics most frequently associated with talented individuals, such as: high levels of expertise; leadership behaviors; creativity; and Initiative stemming from a "can do attitude" based on self-belief. The levels of performance required from individual talent will naturally depend on the needs of the organization and the nature of the work. For example, in the GLCs, organizations in this sector may see talented individuals as those who demonstrate high performance in leadership behaviors by those who draw upon high levels of expertise in a specialist area. Many talent management measures are one-source self-reports that make it difficult to specify the magnitude of the HR practice/outcome and there is controversy regarding the organizational level at which HR effectiveness criterion data should be collected (Gerhart et al., 2002 \& Gerhart et al., 2000).

H3: Talent Management (TM) has significant positive relationship with performance

\section{METHODOLOGY AND DATA}

The sample includes all of the twenty six (26) public listed companies of the GLCs in Malaysia. The present study uses a structured questionnaires to collect the data from the respondents and in constructing the instrument items of the questionnaires, an attempt was made to include questions only if they were necessary in achieving the research objectives. The measurement used for the variables in this study was adapted from the previous studies as stated in table 1 . The respondents in this study were the employees from various hierarchical levels, including the top level, middle level and operational level. It is based on the authority of making decisions of each level. 
Each respondent received a copy of the questionnaire personally (face to face), hence to ensure the highest possible response rate (Zikmund, 2003). The cover letter gave a clear explanation of the purpose behind the research, assuring the respondent anonymity, and an offer to send a copy of a summary of the findings to those who are interested. The questionnaire used a letter head that stated any information provided will be treated with strictest confidential and would be used only for academic purposes.

In order to addresses each of the stated hypotheses in the literature review, a regression analysis was performed to assess the direct and indirect relationships within the proposed model and the stated hypotheses.

$$
\text { Pit }=\alpha 0+\beta 1 \text { EOit }+\beta 2 \text { Slit }+\beta 3 \text { TMit }+\mu \mathrm{t}
$$

Where: where i refers to firm, $t$ refers to time, and $P$ is the firm performance, $\alpha$ refers to estimated constant, EO is firm's entrepreneurship orientation, $\mathrm{SI}$ is firm's strategic Improvisation, TM is firm's talent management and $\mu$ is the standard error.

\section{Table 1: The Survey Items Constructed}

\begin{tabular}{llll}
\hline Section & Title & $\begin{array}{l}\text { Number } \\
\text { of Items }\end{array}$ & Authors \\
\hline
\end{tabular}

A

(i) Measures of Independent Variables

\begin{tabular}{|c|c|c|}
\hline Entrepreneurial Orientation & 9 & Covin and Slevin (1989). \\
\hline Strategic Improvisation & $7+11$ & Jambekar (2007); \\
\hline (Operation Strategy) & & $\begin{array}{l}\text { Skinner (1969); Oltra and } \\
\text { Flor (2010). }\end{array}$ \\
\hline Talent Management & 7 & Pruis (1989). \\
\hline
\end{tabular}

Firm Performance

$9+23$

(Operational Excellence: cost, quality, time, flexibility, social responsibility,enviromental)
Dess and Robinson (1984); Gupta and Govindarajan (1984);

Laugen, et al. (2005); Hubbard (2009); Kuruppuarachchi \& Perera (2010). 


\section{FINDINGS AND DISCUSSION}

\subsection{Test of Early and Late Responses}

According to Armstrong and Overton (1977), firms that respond later are theoretically more similar to non-respondents. This argument is the late respondent would not have probably responded other than they had been extensively given follow up approach. To rule out that non-response bias is a critical concern for this study, a non-response bias test is carried out with the late respondents being used as proxy for non-respondents. During the analysis, T-test was conducted for all variables related in this study. Results from the Ttest are shown in Table 2, shows that there is no statistically significant differences at the 0.05 level for any of the characteristics by the two groups, early respondents and late respondents. Therefore, the researcher assumes that non-response bias is not a critical concern for this study.

Table 2: The T-test Result between Early and Late Respondents

\begin{tabular}{llcccccc}
\hline & $\begin{array}{l}\text { Respon } \\
\text { se Bias }\end{array}$ & $\mathrm{N}$ & Mean & $\begin{array}{c}\text { Std. } \\
\text { Deviation }\end{array}$ & $\begin{array}{c}\text { Std. Error } \\
\text { Mean }\end{array}$ & $\begin{array}{c}\text { T- } \\
\text { value }\end{array}$ & Significance \\
\hline $\begin{array}{l}\text { Entrepreneuri } \\
\text { al Orientation }\end{array}$ & Early & 141 & 3.7063 & .59329 & .07596 & -.663 & .181 \\
& Late & 140 & 3.7736 & .52145 & .06732 & & \\
$\begin{array}{l}\text { Strategic } \\
\text { Improvisation }\end{array}$ & Early & 141 & 3.8823 & .40566 & .05194 & -.309 & .608 \\
& Late & 140 & 3.9045 & .38621 & .04986 & & \\
$\begin{array}{l}\text { Talent } \\
\text { Management }\end{array}$ & Early & 141 & 3.7309 & .51108 & .06544 & .652 & .880 \\
& Late & 140 & 3.7847 & .45393 & .05860 & & \\
$\begin{array}{l}\text { Firm } \\
\text { Performance }\end{array}$ & Early & 61 & 3.6972 & .52335 & .06701 & -.865 & .298 \\
& Late & 60 & 3.7741 & .45250 & .05842 & & \\
\hline
\end{tabular}

\subsection{Descriptive Statistics}

The means and standard deviation of in the entrepreneurial orientation constructs are displayed in Table 3. Mean scores are computed by equally weighting the mean scores of all items. On a five-point scale, the mean scores of the items of entrepreneurial orientation are from the highest of 4.2633 with the lowest of 3.5836 . The standard deviation ranged from 0.68587 to .95082 .

The mean score for the EO construct can be classified as high. According to Mahmood and Rahman (2007), and Mahmood (2005), a mean rating value of 4.21 and above are classified as very high, a mean rating value of between 3.41 and 4.20 as high, and a mean rating of 3.41 and below as moderate. 
Table 3: Means of Entrepreneurial Orientation

\begin{tabular}{|c|c|c|c|}
\hline No. & Statement & Mean & SD \\
\hline 1 & $\begin{array}{l}\text { Our organization searches new technologies, processes, } \\
\text { techniques, and/or product idea }\end{array}$ & 4.2633 & .73317 \\
\hline 2 & Our organization generates creative ideas & 4.0676 & .68587 \\
\hline 3 & $\begin{array}{l}\text { Our organization promotes and champions new ideas to } \\
\text { others }\end{array}$ & 3.8821 & .84053 \\
\hline 4 & $\begin{array}{l}\text { Our organization investigates and secures funds needed to } \\
\text { implement new ideas }\end{array}$ & 3.8327 & .95082 \\
\hline 5 & Top management is an innovative problem solver & 3.7544 & .75606 \\
\hline 6 & $\begin{array}{l}\text { Our organization believes in something to make it happen, } \\
\text { no matter what the odds }\end{array}$ & 3.8826 & .77718 \\
\hline 7 & $\begin{array}{l}\text { Our organization loves being a champion for our ideas, } \\
\text { even against others' opposition }\end{array}$ & 3.7544 & .86201 \\
\hline \multirow[t]{2}{*}{8} & $\begin{array}{l}\text { Our organization spots a business opportunity long before } \\
\text { others can }\end{array}$ & 3.7046 & .86702 \\
\hline & Top management prefers the risky business option & & \\
\hline 9 & & 3.5836 & .89500 \\
\hline
\end{tabular}

The means and standard deviations of all items of strategic improvisation are shown in Table 4. All the items were measured on a five point scale. The mean scores for SI ranged from 3.7651 to 3.9609 giving an overall mean of 3.8607. This shows that the degree of strategic improvisation among the GLCs was relatively high. 
Table 4: Means of Strategic Improvisation

\begin{tabular}{|c|c|c|c|}
\hline No. & Statement & Mean & SD \\
\hline 1 & $\begin{array}{l}\text { Top management responds in the moment to unexpected } \\
\text { problems }\end{array}$ & 3.7758 & .75799 \\
\hline 2 & $\begin{array}{l}\text { Top management identifies opportunities for new work } \\
\text { process }\end{array}$ & 3.9181 & .78631 \\
\hline 3 & $\begin{array}{l}\text { Top management explores a wide variety of approaches } \\
\text { to a problem }\end{array}$ & 3.8399 & .86560 \\
\hline 4. & $\begin{array}{l}\text { Top management creates multiple courses of action } \\
\text { during planning }\end{array}$ & 3.8221 & .75381 \\
\hline 5 & $\begin{array}{l}\text { Top management maintains productivity in challenging } \\
\text { circumstances }\end{array}$ & 3.9609 & .74299 \\
\hline 6. & $\begin{array}{l}\text { A top management team adopts the company strategy } \\
\text { adequately to changes in the organization's business } \\
\text { environment }\end{array}$ & 3.9431 & .75850 \\
\hline 7 & $\begin{array}{l}\text { Top management believes that their initial impressions of } \\
\text { situations are almost always right }\end{array}$ & 3.7651 & .70836 \\
\hline
\end{tabular}

The means and standard deviations of all items of talent management are shown in Table 5. All the items were measured on a five point scale. The mean scores for TM ranged from 3.7224 to 3.9609 giving an overall mean of 3.8331. This shows that the degree of talent management among the GLCs was relatively high. 
Table 5: Means of Talent Management

\begin{tabular}{lllll}
\hline No. & Statement & Mean & SD \\
\hline 1 & $\begin{array}{l}\text { Top management views workforce effectiveness as } \\
\text { important in delivering business results }\end{array}$ & 3.9609 & .79859 \\
2 & $\begin{array}{l}\text { Our organization has a workforce management strategy } \\
\text { that is explicitly linked to the overall business strategy }\end{array}$ & 3.8719 & .85646 \\
& $\begin{array}{l}\text { Our organization understands and addresses workforce } \\
\text { attitudes }\end{array}$ & 3.8221 & .77714 \\
4 & $\begin{array}{l}\text { Metrics are used to provide input into strategic workforce } \\
\text { planning decisions }\end{array}$ & 3.7419 & .82979 \\
\hline $\begin{array}{l}\text { Our organization attracts, retains, values, and fully utilizes } \\
\text { a diverse workforce }\end{array}$ & 3.7224 & .90307 \\
\hline & $\begin{array}{l}\text { Our organization identifies high potential and key } \\
\text { employees and had programs to retain them }\end{array}$ & 3.8256 & .96816 \\
\hline & $\begin{array}{l}\text { Our organization has a succession management capability } \\
\text { that guides the development of leadership talent }\end{array}$ & 3.8221 & .90060 \\
\hline
\end{tabular}

The means and standard deviations of all items for firm performance are shown in Table 6. All items were measured on a five-point scale. The mean scores for performance ranged from 3.79 to 4.08 , giving an overall mean of 3.94. This shows that the performance of the banks was relatively high for the past three years. 
Table 6: Means of Performance

\begin{tabular}{|c|c|c|c|c|c|}
\hline \multirow{2}{*}{ No } & \multirow{2}{*}{ Statement } & \multicolumn{2}{|c|}{ Importance } & \multicolumn{2}{|c|}{ Satisfaction } \\
\hline & & Mean & SD & Mean & SD \\
\hline 1 & Return on investment & 4.4892 & .754 & 3.8869 & .9007 \\
\hline 2 & Net profit & 4.5396 & .8262 & 3.8768 & .9757 \\
\hline 3 & Control of operational expenses & 4.446 & .7664 & 3.8102 & .9457 \\
\hline 4 & Market share & 4.2336 & .8366 & 3.7044 & .9666 \\
\hline 5 & Product/service cycle time & 4.2873 & .7744 & 3.7491 & .8364 \\
\hline 6 & Customer service level & 4.5 & .7683 & 3.9638 & .826 \\
\hline 7 & Inventory levels & 4.1691 & .8646 & 3.7194 & .9272 \\
\hline 8 & Resource utilization & 4.2996 & .86 & 3.7527 & .9134 \\
\hline 9 & Sales growth & 4.4604 & .7625 & 3.8561 & .9134 \\
\hline 10 & Sales volume & 4.4712 & .739 & 3.9532 & .9238 \\
\hline
\end{tabular}

\subsection{Regressions Analysis}

In the multiple regression analysis, the dependent variable of firm performance was regressed against the independent variables. As shown in Table 4, the regression model was found to be fit $(F=70.056$; Sig. $=.000)$. The $R 2$ indicates the coefficient of determination of the predictor variables on the dependent variable. As indicated from the table, R2 showed a value on .605, which means that $60.5 \%$ of the variance in firm performance could be explained significantly and collectively by the predictor variables. Collectively, the independent variables were found to be able to explain $59.7 \%$ of the variance in firm performance, which means that the model fit is valid across different sample sizes and can be validly generalized to the study population.

Based on the regression in table 7, the result shows that all the variables were positively significant. As indicated earlier, multiple regression analysis can also determine which one among the predictor variables that has the most influence on firm performance. As shown in Table 7, (SI) showed the biggest beta value of 0.333 , which it was significant at 0.001 levels. 
Table 7: Regression Analysis

\begin{tabular}{cccccc}
\hline \multicolumn{7}{c}{ Coefficients $^{\mathrm{a}}$} \\
Model & Unstandardized Coefficients & $\begin{array}{c}\text { Standardized } \\
\text { Coefficients }\end{array}$ & $\mathrm{T}$ & Sig. \\
& B & Std. Error & Beta & & \\
(Constant) & .911 & .181 & & 5.030 & .000 \\
EO & .152 & .051 & .156 & 2.975 & .003 \\
SI & .308 & .061 & .333 & 5.040 & .000 \\
YTM & .108 & .037 & .149 & 2.948 & .003 \\
\hline
\end{tabular}

a. Dependent Variable: $\mathrm{P}$

SI plays the most important role in predicting firm performance. EO beta value is 0.156 also considered to be high as compare to TM which is 0.149 with significant value of, .003 . Table 8 indicated the results of the overall model.

Table 8: Regressions of EO, SI and TM on performance

\begin{tabular}{lrrrrrr}
\multicolumn{7}{c}{ ANOVA $^{\text {a }}$} \\
Model & Sum of Squares & df & Mean Square & F & Sig. \\
\hline & Regression & 54.410 & 6 & 9.068 & 70.056 & $.000^{\text {b }}$ \\
1 & Residual & 35.468 & 274 & .129 & \\
& Total & 89.878 & 280 & & \\
\end{tabular}

The main objective of this study was to determine the relationship of EO, SI and TM and effect on the organization performance among GLCs companies in Malaysia. Based on the result, all three hypotheses are confirmed, which are EO, SI and TM whereby it indicates that those three variables have a significant positive relationship with GLC's performance. The understanding of this result is vital as the result showed an interesting fact, despite of a long and numerous arguments between scholars, which result in mutual agreement on the suggestion of a positive relationship between the entire tested variable with GLC's performance. Entrepreneurial orientation is a key way to develop distinctive competencies such as product innovation (Hitt \& Ireland, 1986). This findings showed that EO is a key driver of enhancing the companies' performance. 
Thus, it also proves, that EO can't be simply ignored by the top management once they need to enhance the performance. Additionally, EO is a vital variable in improving the GLC's performance, based on the theoretical understanding. This result was in line with previous studies such as Wiklund and Shepherd (2004), Yang (2008), Runyan , Droge, and Swinney (2008) and Wang (2008).

The result of this study also confirm that there is a significant positive relationship between SI and GLC's performance in line with the result from the previous scholars. Improvisation enables managers to continually learn while working and act spontaneously and creatively to consistently move products and services out of the door (Brown \& Eisenhardt, 1997). By practicing improvisation, organizations could gain a better understanding on how individual and groups in organizations cope with and coordinate the conflicting demands of existing time perspectives (Crossan, Pina e Cunha, Vera, \& Cunha, 2005); learn and adapt under time pressures (Vera \& Crossan, 2005); and remain flexible under turbulent environments (Cunha, Cunha, \& Kamoche, 1999).

\section{CONCLUSION}

The study explored on the relationship among EO, SI and TM and the performance of the GLCs. The outcomes of the study identified variables that are important in explaining the achievement of performance in the GLCs. The main objective of this study is to understand the best management practices of GLCs in Malaysia in terms entrepreneurial orientation, strategic improvisation and talent management and their relationships to firm performance. The study improves upon the existing theoretical framework from the literature of best practices on performance and the new knowledge generated from this study could assist theory building efforts particularly in the strategic and best practice management field. Furthermore, the findings of the study supported the RBV theories. The RBV on inimitable recourses and dynamic capabilities suggest that organizational should have their own competence according to knowledge resources. These competencies must be rare and unique. Moreover, researchers also found many of resources and capabilities on which competitive advantage is based reside in the operations function (Coates \& McDermott, 2002; Lucas \& Kirillova, 2011). On the managerial implication of the study, the study finds several statistically significant relationships with practical applications. Therefore GLCs should give the right priority to the implementation of the best practices to ensure favorable results.

\section{REFERENCES}

- $\quad$ Alegre, J., Lapiedra, R., Chiva, R. (2006). A literature-based innovation output analysis: Implications for innovation capacity, International Journal of Innovation Management, 9(4), pp. 385-399.

- $\quad$ Armstrong, J., Overton, T. (1977). Estimating nonresponse bias in mail surveys. Journal of Marketing Research, 14, pp. 396-402. 
- $\quad$ Ang, J. S., \& Ding, D. K. (2006). Government ownership and the performance of government-linked companies: the case of Singapore, Journal of Multinational Financial Management, 16, pp. 64-88.

- Axelrod, B., Handfield-Jones, H. and Michaels, E. (2002) “A new game plan for C players", Harvard Business Review, January, pp. 81-88.

- Barney, J. (1991). Firm resources and sustained competitive advantage, Journal of Management, Vol. 17(1), pp. 99-120.

- Baker T, Miner A, Eesley D, 2003. Improvising firms: bri-colage, account giving, and improvisational competency in the founding process. Research Policy 32: pp. 255-276.

- $\quad$ Brown, S. L., \& Eisenhardt, K. M. (1997). The art of continuous change: linking complexity theory and time-paced evolution in relentlessly shifting organizations. Administrative Science Quarterly.

- $\quad$ Coates, T., McDermott, C. (2002). An exploratory analysis of new competencies: a resource based view perspective. Journal of Operations Management, 20(5), pp. 435-450.

- Covin, J. G., Slevin, D. P. (1989). Strategic management of small firms in hostile and benign environments. Strategic Management Journal, 10, pp. 75-87.

- Crossan, M., Cunha, M. P., Vera, D., and Cunha, J. (2005). Time and organizational improvisation. Academy of Management Review, 30(1), pp. 129-145.

- Crossan, M. M., Pina e Cunha, M., Vera, D., Cunha, J. (2005). Time and organizational improvisation. Academy of Management Review.

- Cunha, M. P., Cunha, J. V., Kamoche, K. (1999). Organizational improvisation: what, when, how, and why. International Journal of Management Review, 1(3), pp. 299-341.

- Dess, G., Robinson, R. (1984). Measuring organizational performance in the absence of objective measures: The case of the private-held firm and conglomerate business unit, Strategic Management Journal, Vol. 5(3), pp. 265273.

- Fahy, J. (2000). The resource-based view of the firm: some stumbling-blocks on the road to understanding sustainable competitive advantage, Journal of European Industrial Training, Vol. 24(2/3/4), pp. 94-104. 
- Gupta, A., Govindarajan, V. (1991). Knowledge flows and the structure of control within multinational corporations, Academy of Management Review, Vol. 16(4), pp. 768-792.

- Hitt, M. A., \& Ireland, R. D. (1986). Relationships among corporate level distinctive competencies, diversification strategy, corporate strategy and performance. Journal of Management Studies.

- Hmieleski, K. M., \& Corbett, A. C. (2008). The contrasting interaction effects of improvisational behaviour with entrepreneurial self-efficacy on new venture performance and entrepreneur work satisfaction. Journal of Business Venturing, 23(4), pp. 482-496.

- Hubbard, G. (2009). Managing organizational performance: Beyond the triple bottom line, Business Strategy and the Environment, Vol. 19, pp. 177-191.

- Jambekar, A., \& Pelc, K. (2007). Improvisation model for team performance enhancement in a manufacturing environment. Team Performance Management, 13(7/8), pp. 259-274.

- Janney, J. J., \& Dess, G. G. (2006). The risk concept for entrepreneurs reconsidered: new challenges to the conventional wisdom. Journal of Business Venturing, 21.

- Kuruppuarachchi, D., \& Perera, H. S. C. (2010). Impact of TQM and technology management on operations performance. Journal of Operations Management, Vol. 23(47).

- $\quad$ Kamoche, K., Cunha, M.P. and Cunha, J.V. (2003). Towards a theory of organizational improvisation: Looking beyond jazz metaphor. Journal of Management Studies, 40(8), pp. 2023-2051.

- Kapelko, M. (2006). Evaluating efficiency in the framework of resource-based view of the firm: evidence from polish and spanish textile and clothing Industry,

- $\quad$ Laugen, B. T., Acur, N., Boer, H., \& Frick. J. (2005). Best manufacturing practices: What do the best performing companies do? International Journal of Operation \& Production Management, 25, pp. 131-150.

- $\quad$ Lin, C., Tsai, H., Wu, Y., Kiang, M. (2012). A fuzzy quantitative VRIO-based framework for evaluating organizational activities. Management Decision, Vol. 50(8), pp. 1396-1411. 
- $\quad$ Lucas, M., Kirillova, O. (2011). Reconciling the resource-based and competitive positioning perspectives on manufacturing flexibility. Journal of Manufacturing Technology Management, Vol. 22(2), pp. 189-203.

- March, J.G. (1991). Exploration and exploitation in organizational learning. Organizational Science, 2, pp. 71-87.

- McGrath, R.G. (2001). Exploratory learning, innovative capacity, and managerial oversight. Academy of Management Journal, 44(1), pp. 118-131.

- Moorman, C. and Miner, A.S. (1998b). The convergence between planning and execution: Improvisation in new product development. Journal of Marketing, 62(3), pp. 1-20

- Mullins J, Komisar R. 2009. Getting to Plan B: Breaking through to a Better Business Model. Harvard Business School Press: Boston, MA.

- Musa, M. B. (2007). Towards A Competitive Malaysia: Development Changes in the 21st Century. Strategic Information and Research Development Centre.

- Oltra, M. J., \& Flor, M. L. (2010). The moderating effect of business strategy on the relationship between operations strategy and firm's results. International Journal of Operations \& Production Management, 30(6), pp. 612-638.

- O'Regan, N., Ghobadian, A. (2004). Short- and long-term performance in manufacturing SMEs: different targets, different drivers. International Journal of Productivity and Performance Management, 53(5), pp. 405-424.

- $\quad$ Pruis, E. (1989). The five key principles for talent development. Industrial and Commercial Training, Vol. 43(4), pp. 206-216.

- Runyan, R., Droge, C., Swinney, J., (2008). Entrepreneurial orientation versus small business orientation: what are their relationships to firm performance? Journal of Small Business Management, 46(4), pp. 567-588.

- Salaman, G., Storey, J., Billsberry, J. (2005). Strategic Human Resource Management: Theory and Practice. London: SAGE Publication Ltd.

- $\quad$ Singh, K., \& Ang, S. H. (1999). Government in business: an empirical analysis of the strategies and success of government linked corporations in Singapore. Academy of Management, pp. 1-6.

- $\quad$ Skinner, W. (1969). Manufacturing: the missing link in corporate strategy. Harvard Business Review, 47, pp. 136-145. 
- $\quad$ Souchon, A.L., \& Hughes, P. (2007). Improvising export decisions: a contingency theory perspective. International and Cross-cultural Marketing, Track 8.

- Tansley, C. (2011). What do we mean by the term "talent" in talent management? Industrial and Commercial Training, Vol. 43(5), pp. 266-274.

- $\quad$ Ting, I., Lean, H. (2011). Capital structure of government-linked companies in Malaysia. Asian Academy of Management Journal of Accounting and Finance, Vol. 7(2), pp. 137-156.

- Vietor. (2007). How countries compete: strategy, structure, and government in the global economy. Harvard: Harvard Business School Press.

- Vera, D., \& Crossan, M. (2005). Improvisation and innovative performance in teams. Organization Science, 16(3), pp. 203-224

- Wang, C. L. (2008). Entrepreneurial orientation, learning orientation, and firm performance. Entrepreneurship Theory and Practice, 32(4), pp. 635-656.

- Wiklund, J. \& Shepherd, D. (2005). Entrepreneurial orientation and small business performance: a configurational approach. Journal of Business Venturing, 20(1), pp. 71-89.

- Yang, C-W. (2008). The relationships among leadership styles, entrepreneurial orientation, and business performance. Managing Global Transitions 6(3), pp. 257-275.

- Zahra, S. A., \& Covin, J. G. (1995). Contextual influences on the corporate entrepreneurship-performance relationship: a longitudinal analysis. Journal of Business Venturing, 10(1), pp. 43-58.

- Zikmund, W. G. (2003). Business research methods (7th ed). Ohio: Thompson SouthWestern. 